\title{
PENERAPAN METODE NUMBER HEAD TOGETHER (NHT) UNTUK MENINGKATKAN HASIL BELAJAR DAN KEAKTIFAN SISWA PADA MATA PELAJARAN MEKANIKA TEKNIK KELAS X KOMPETENSI KEAHLIAN DESAIN PEMODELAN DAN INFORMASI BANGUNAN (DPIB) DI SMK NEGERI 5 SURAKARTA
}

\author{
Gilang Rahmadi', Sukatiman², Rima Sri Agustin ${ }^{2}$ \\ E-mail : gilangrahmadi4.gr@gmail.com
}

\begin{abstract}
ABSTRAK
Penelitian ini bertujuan untuk mengetahui peningkatan hasil belajar dan keaktifan siswa pada mata pelajaran Mekanika Teknik dengan metode pembelajaran Number Head Together (NHT) di kelas X DPIB di SMK Negeri 5 Surakarta. Metode Penelitianya adalah Penelitian Tindakan Kelas yang dilaksanakan di kelas X DPIB SMK Negeri 5 Surakarta dalam dua siklus. Setiap siklus terdiri dari tahap perencanaan, tahap pelaksanaan, tahap observasi dan refleksi. Teknik pengumpulan data pada penelitian ini menggunakan tes dan lembar observasi. Analisis data menggunakan deskriptif kualitatif. Berdasarkan hasil penelitian, hasil belajar siswa pada pra siklus sebesar 31\%. Setelah diterapkan metode pembelajaran Number Head Together (NHT), pada siklus I mengalami peningkatan dengan persentase ketuntasan 91,18\%. Siklus II persentase ketuntasan $97 \%$. Sedangkan keaktifan siswa pada pra siklus prosesntase siswa aktif sebesar 38,24\%, setelah diterapkan metode NHT pada siklus I prosentase siswa aktif sebesar $68,75 \%$, dan siklus II meningkat menjadi 82,35\%. Dengan demikian, Metode Pembelajaran Number HeadTogether (NHT) dapat meningkatkan hasil belajar dan keaktifan siswa pada mata pelajaran Mekanika Teknik di SMK Negeri 5 Surakarta karena memenuhi prosentase ketuntasan yaitu sebesar $80 \%$ dari 34 siswa.
\end{abstract}

Kata Kunci: Number Head Together (NHT), Hasil Belajar, Keaktifan Siswa, Mekanika Teknik

\footnotetext{
${ }^{1}$ Mahasiswa Program Studi Pendidikan Teknik Bangunan FKIP UNS

${ }^{2}$ Pengajar Program Studi Pendidikan Teknik Bangunan FKIP UNS
} 


\title{
APPLICATION OF THE METHOD OF NUMBER HEAD TOGETHER (NHT) TO IMPROVE LEARNING OUTCOMES AND THE LIVELINESS OF THE STUDENTS ON THE MECHANICS TECHNICAL OF $X^{\text {th }}$ GRADE STUDENT AT VOCATIONAL SECONDARY SCHOOL $5^{\text {th }}$ OF SURAKARTA
}

\author{
Gilang Rahmadi', Sukatiman ${ }^{2}$, Rima Sri Agustin ${ }^{2}$ \\ E-mail : gilangrahmadi4.gr@gmail.com
}

\begin{abstract}
This research aims to know learning outcomes and improvement of the liveliness of the students on the subjects of Mechanics Technical with Number Head Together method in class X DPIB at SMK Negeri 5. This Research method was Research Action class that is implemented in the class X DPIB SMK Negeri 5 Surakarta in two cycles. Each cycle consists of the planning phase, stage, stage of observation and reflection. Data collection techniques in the research of using tests and observation sheets. Data analysis using qualitative descriptive. Based on the results of the research, learning outcomes on a precycle amounted to 31\%. After leearning applied Number Head Together (NHT), cycle I has increased amounted to 91.18\%. Cycle II amounted to 97\%. While the liveliness of students on pre-cycle amounted to $38.24 \%$, after having applied the method of NHT on cycle I percentage of active students was $68.75 \%$, and cycle II increased to $82.35 \%$. Thus, Number Head Together (NHT) can improve Learning Outcomes and the liveliness of the students on the subjects of Mechanics Technical at SMK Negeri 5 Surakarta since meet the percentage of thoroughly that is as big as $80 \%$ of the 34 students.
\end{abstract}

Keywords: Number Head Together (NHT), Learning Outcomes , The Liveliness of Students, Mechanics Technical

\footnotetext{
${ }^{1}$ Student of Civil Engineering of Education FKIP UNS

${ }^{2}$ Lecturer of Civil Engineering of Education FKIP UNS
} 


\section{PENDAHULUAN}

Mekanika Teknik merupakan mata pelajaran yang diajarkan kepada siswa kelas X di SMK Negeri 5 Surakarta. Tujuannya siswa diberi pembekalan dasar akademik sehingga siswa mampu bekerja sesuai dengan keahliannya. Namun fakta pelaksanaan di lapangan, hasil belajar siswa cenderung kurang maksimal. Nilai rata-rata siswa kurang mencapai batas ketuntasan minimal yang ditentukan. Dari data yang diperoleh hasil observasi khususnya pada pokok bahasan gaya batang pada rangka sederhana ada $31,25 \%$ (10 siswa) dari 34 siswa yang tidak mendapat nilai sesuai KKM yang ditentukan yaitu 76. Berdasarkan hasil observasi pada saat proses pra siklus didapatkan data $61,76 \%$ (21 siswa) dari 34 yang tidak aktif sehingga sebagian besar siswa kurang berpartisipasi ketika pembelajaran berlangsung. Selain itu, penggunaan metode ceramah yang kurang tepat, karena dari awal sampai akhir proses pembelajaran masih didominasi oleh Guru, sehingga pembelajaran terkesan monoton.

Oleh karena permasalahan tersebut, peneliti berupaya mencari solusi yang efektif untuk meningkatkan hasil belajar dan keaktifan siswa. Dalam hal ini model pembelajaran kooperatif menjadi salah satu solusi. Peneliti melihat bahwa metode pembelajaran Number Head Together (NHT) dapat menciptakan kondisi belajar yang menarik. Selain itu Metode Number Head Together (NHT) diharapkan mampu melibatkan keaktifan siswa untuk melakukan penemuannya sendiri dalam menganalisis materi. Sehingga dalam pelaksanaan pembelajaran tersebut tidak hanya berpusat pada guru melainkan siswa juga dituntut untuk aktif berkomunikasi dan bekerja sama, sehingga dapat meningkatkan hasil belajar siswa dalam proses pembelajaran Mekanika Teknik

\section{METODE PENELITIAN.}

Metode Penelitian ini termasuk Penelitian Tindakan Kelas yang biasa disingkat dengan PTK adalah action research yang dilakukan di kelas. Peneliti berencana membagi tahap penelitian menjadi tiga, yaitu pra siklus kondisi sebelum diterapkan metode NHT, yang terdiri dari 2 siklus. Metode pembelajaran Number Head Together adalah strategi pembelajaran yang bertujuan untuk memberikan akuntabilitas individu dalam diskusi kelompok (Huda, 2016). Langkah-langkah penerapan Number Head Together (Huda 2016: 210): (1) Numbering. (2) Guru memberikan lembar. (3) Kelompok berdiskusi. (4) Guru memanggil nomor peserta (5) Siswa mengerjakan hasil diskusi di depan kelas. Metode pembelajaran NHT tersebut diharapkan hasil belajar dan keaktifan siswa kelas $\mathrm{X}$ pada mata pelajaran Mekanika Teknik di SMK N 5 Surakarta dapat meningkatkan.

Teknik pengumpulan data dalam penelitian ini menggunakan (1) Dokumentasi, (2) Tes dan (3) Observasi. Instrumen yang digunakan dalam pengambilan data adalah soal tes dan lembar observasi keaktifan siswa. Teknik Analisa Data yang digunakan yaitu pengumpulan data dalam proses penelitian dalam bentuk interaktif. Interatif disini terdiri dari reduksi data, penyajian data, dan kesimpulan dengan pengumpulan data sebagai suatu proses siklus.

\section{HASIL PENELITIAN DAN PEMBAHASAN}

A. Deskripsi Data

Pada tahap awal, peneliti terlebih dahulu melakukan observasi tehadap pelaksanaan proses pembelajaran siswa kelas X Desain Permodelan dan Informasi Bangunan (DPIB) mata pelajaran Mekanika Teknik. 
Hasil observasi yang dilakukan proses pembelajaran masih kurang maksimal. Data hasil ulangan harian semester I sebelum diterapkan metode pembelajaran NHT dari siswa yang berjumlah 34, didapatkan data sebagai berikut:

1. Hasil Belajar Mekanika Teknik

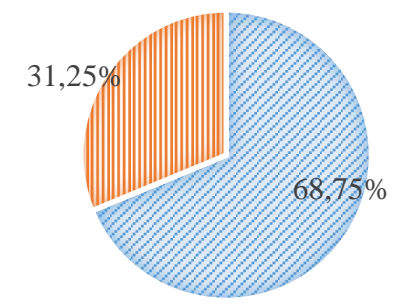

- Siswa Tuntas " Siswa Tidak Tuntas

Gambar 1. Diagram Persentase

Ketuntasan Pra Siklus Ranah

Pengetahuan dan Ranah Keterampilan

\section{Keaktifan Siswa}

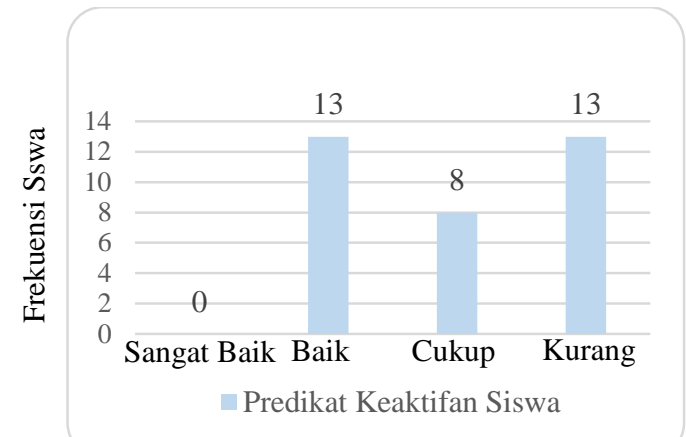

Gambar 2. Diagram Predikat Keaktifan Siswa Pra Siklus

Dari data diatas dapat dilihat bahwa hasil belajar dan keaktifan siswa masih kurang optimal.

B. Deskripsi Hasil Tindakan Tiap Siklus

1. Deskripsi Hasil Tindakan siklus I sebagai berikut :

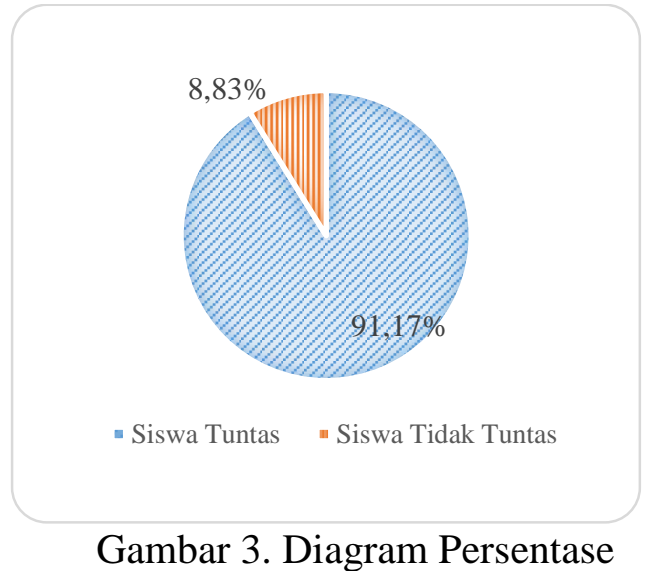

Ketuntasan Siklus I Ranah Pengetahuan dan Ranah Keterampilan

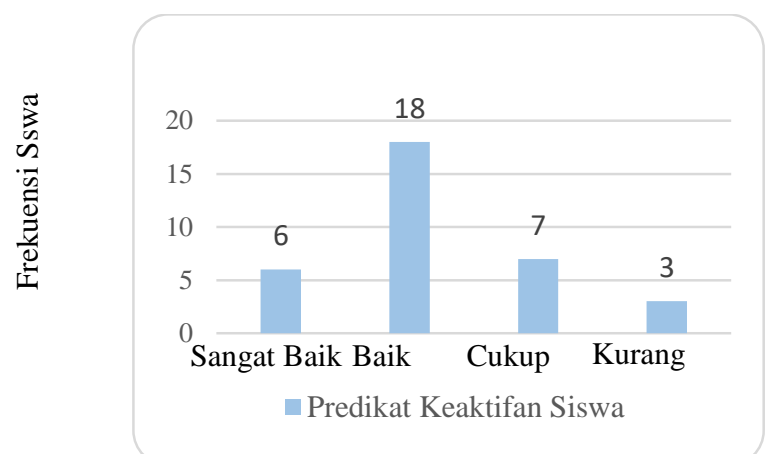

Gambar 4. Diagram Predikat Keaktifan Siswa Siklus I

Perencanaan penelitian tindakan kelas siklus pertama ini berdasarkan hasil pra siklus yang dilakukan pada saat observasi sebelum penerapan metode pembelajaran Number Head Together (NHT) di kelas X DPIB SMK Negeri 5 Surakarta. Siklus I dilakukan pada hari Jumat, 2 Maret 2018 dengan alokasi waktu $3 \times 45$ menit pada jam pelajaran ke 1-3 dan Maret 2018 dengan alokasi waktu 3 x45 menit pada jam ke 1-3. Dalam pelaksanaan penelitian siklus I meliputi beberapa tahap. Mulai dari tahap perencanaan sampai tahap refleksi penilitian dan dilaksanakan secara bertahap. Dari siklus I ini akan diadakan refleksi untuk memperbaiki hasil belajar dan keaktifan siswa.

2. Deskripsi Hasil Tindakan Siklus II

Siklus II digunakan untuk memperbaiki siklus I. Materi pada 
siklus II yaitu mengenai analisis gaya batang pada rangka sederhana dengan metode Cremona. Didapatkan hasil data sebagai berikut :

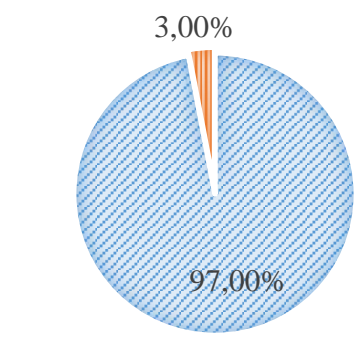

- Siswa Tuntas - Siswa Tidak Tuntas

Gambar 5. Diagram Persentase Ketuntasan Siklus II Ranah Pengetahuan dan Ranah Keterampilan

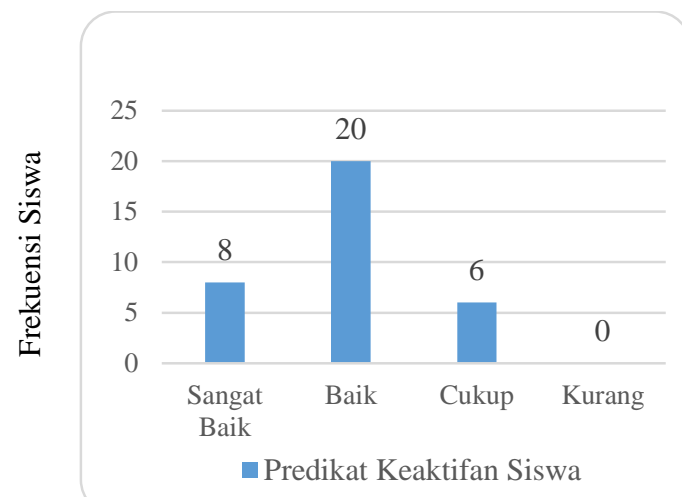

Gambar 6. Diagram Predikat Keaktifan Siswa Siklus II

\section{Perbandingan Hasil Tindakan Antar Siklus}

Pada hasil perbandingan tindakan antar siklus ini meliputi hasil tindakan siswa sebelum dilakukannya Metode Number Head Together ( pra siklus ) dan sesudah diterapkannya Metode Number Head Together (siklus I dan siklus II) menjadikan siswa bertambah aktif. Perbandingan hasil belajar siswa tiap siklus sebagai berikut :

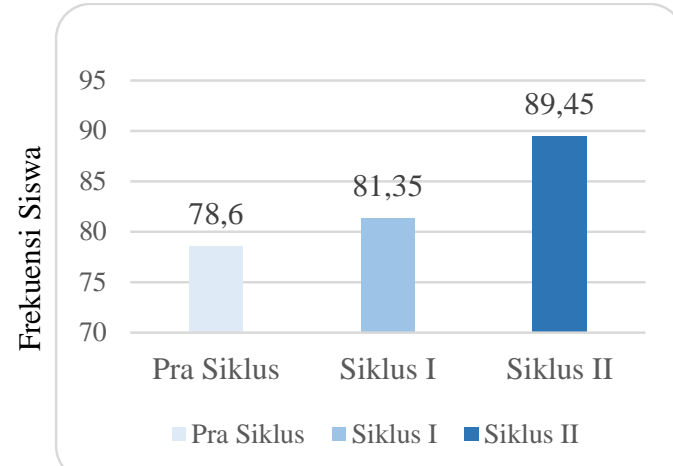

Gambar 7. Diagram Perbandingan Rata - rata Hasil Belajar

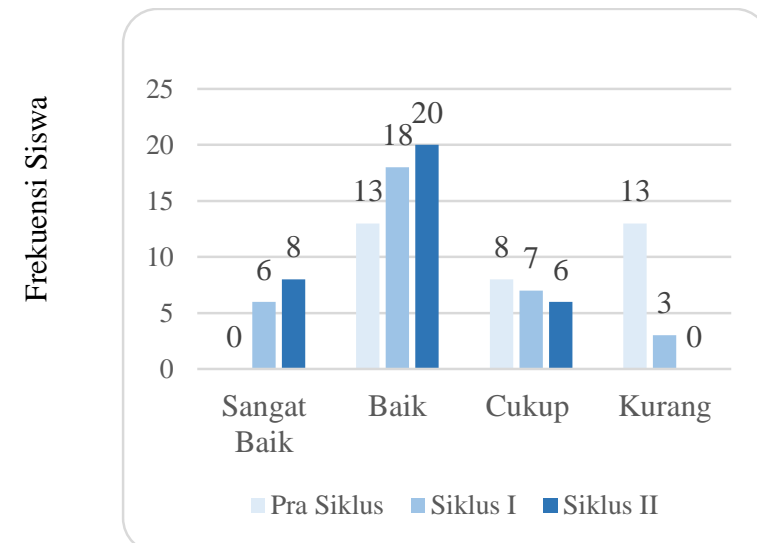

Gambar 8. Diagram Pencapaian Predikat Keaktifan Siswa

D. Pembahasan Hasil Analisis

Di bawah ini merupakan pembahasan setiap siklus, berikut penjelasannya :

1. Pra Siklus

Proses penelitian pra-siklus, peneliti mengadakan observasi kondisi kelas pada saat proses pembelajaran sebelum Number Head Together (NHT) diterapkan. Nilai rata-rata kelas sebesar 78,60 dengan persentase ketuntasan $68,75 \%$ (20 siswa dari 34 siswa) dimana nilai rat-rata kelas yang diperoleh masih jauh dari KKM yaitu sebesar 76. Sedangkan hasil observasi keaktifan pada saat proses pembelajaran Mekanika Teknik didapatkan data $61,76 \% \quad$ (21 siswa) dari 34 yang tidak aktif. Dari keaktifan dan hasil belajar siswa yang diperoleh, masih jauh dengan indikator yang telah ditetapkan. 
2. Siklus I

Data hasil penelitian siklus I merupakan penerapan Metode pembelajaran Number Head Toether (NHT), diperoleh sebagai berikut :

a. Hasil Belajar

Hasil ranah pengetahuan dan keterampilan didapat rata-rata sebesar 81,35 dengan persentase ketuntasan $91,18 \%$ dengan 31 siswa dari 34 siswa.

b. Keakifan siswa

Hasil Keaktifan siswa yang mendapat predikat sangat baik (SB) dan baik (B) sebanyak 28 siswa dari 34 siswa.

3. Siklus II

Data hasil penelitian siklus II merupakan hasil refleksi dari siklus I. Pada siklus II mengalami peningkatan yang sangat baik dalam keaktifan siswa dan hasil belajar yang dicapai juga meningkat sudah mencapai indiaktor penelitian yang ditentukan. Berikut data hasil penelitian siklus II:

a. Hasil Belajar

Hasil ranah pengetahuan didapat rata-rata sebesar 89,45 dengan persentase ketuntasan $97 \%$ dengan 33 siswa dari 34 siswa, jadi mengalami peningkatan.

b. Keaktifan siswa

Hasil Keaktifan siswa yang mendapat predikat Sangat Baik (SB) 9 siswa dan Baik (B) sebanyak 24 siswa.

\section{SIMPULAN}

Metode Pembelajaran Number Head Together (NHT) dapat meningkatkan hasil belajar dan keaktifan siswa pada mata pelajaran Mekanika Teknik siswa kelas X DPIB di SMKN 5 Surakarta.

1. Berdasarkan hasil penelitian didapatkan data sebaga berikut, yaitu pada saat pra siklus sebesar $31 \%(10$ siswa) yang nilainya di atas KKM, sedangkan Setelah diterapkan metode pembelajaran Number Head Together
(NHT) pada siklus I meningkat menjadi $60 \%$ dengan persentase ketuntasan 91,18 \% (31 siswa dari 34 siswa). Rata-rata kelas pada siklus II sebesar 89,45 yang berarti ketuntasannya menjadi $97 \%$ (33 siswa dari 34 siswa).

2. Berdasarkan hasil penelitian, keaktifan siswa pada proses pembelajaran, didapatkan data sebagai berikut yaitu pada pra siklus siswa cenderung pasif karena hasil prosentase siswa aktif hanya sebesar $38,24 \%$, hal ini masih jauh dari target ketuntasan keaktifan siswa yaitu sebesar 80\%. Setelah diterapkan metode pembelajaran Number Head Together (NHT) pada siklus I prosentase siswa aktif sebesar $68,75 \%$. Pada siklus II prosentase siswa aktif meningkat lagi menjadi 82,35\%. Dengan demikian target ketuntasan prosentase siswa aktif sudah tercapai.

\section{DAFTAR PUSTAKA}

Depdiknas. (2003). Kurikulum 2004 Standar Kompetensi Sekolah Dasar. Jakarta: Depdiknas. Diperoleh 19 Agustus 2017, dari: http://repository.upi.edu/540/9/S PGSD_0902843_BIBLIOGRA PHY.pdf

Dimyati dan Mudjiono. (2010). Belajar dan Pembelajaran. Jakarta: Rineka Cipta.

Hamalik, Oemar. (2017). Proses Belajar Mengajar. Jakarta: PT Bumi Aksara.

Huda, Miftahul. (2017). Cooperative Learning. Yogyakarta: Pustaka Pelajar.

Isjoni. (2016). Cooperative Learning Efektifitas Pembelajaran Kelompok. Bandung: Alfabeta. 
Lie, A. (2004). Cooperative Learning: Memperaktikkan Cooperative Learning di Ruang-RuangKelas. Jakarta: Grasindo.

Rahmawati, Anis. (2016). Mekanika Teknik II. Surakarta : UNS Press

Rohman dan Amri. (2013). Metode Pembelajaran. Jakarta : Prestasi Pustaka

Rosyada, Dede. (2015).Student Center Learning (SCL). Diperoleh pada November 2017, dari http://uinjkt.co.id/SCL/

Rusman. (2016). Model-model Pembelajaran. Jakarta : PT Raja Grafindo Persada

Sa'ud. (2009). Belajar dan Pembelajaran. Bandung : Alfabeta

Suhardjono. (2017). Penelitian Tindakan Kelas (Edisi Revisi). Jakarta : Bumi Akasara

Sunandar, Shodiq. (2012). Hakikat Keaktifan Belajar (Online). (http://m4ya5a.blogspot.com/2012/05/hakik at-kekatifan-belajar.html) Diakses 12 April 2018.

Supardi. (2017). Penelitian Tindakan Kelas (Edisi Revisi). Jakarta : Bumi Akasara

Suprijono, Agus. (2014). Cooperative Learning Teori dan Aplikasi PAIKEM. Pustaka Pelajar. Yogyakarta.

Suyadi. (2015). Strategi Pembelajaran Pendidikan Karakter. Bandung : PT. Remaja Rosdakarya Offset

Tim Penulis. (2016). Pedoman Penulisan Skripsi. Surakarta: FKIP UNS.
Trianto. (2010). Mendesain Model Pembelajaran Kooperatif. Jakarta : Kencana 